\title{
PENERAPAN REGRESI LOGISTIK DALAM PENENTUAN FAKTOR YANG MEMPENGARUHI JUMLAH WISATAWAN ECOTOURISM DESA BEDONO
}

\author{
Wilis Ari Setyati, Sunaryo, Arya Rezagama, Abel Kristanto Widodo, \\ M. Faisal Afa Yulianto \\ Program Studi Ilmu Kelautan, Fakultas Perikanan dan IImu Kelautan, \\ Universitas Diponegoro, Semarang, Indonesia \\ E-mail: wilisarisetyati@yahoo.co.id
}

Received December 2019, Accepted February 2020

\begin{abstract}
ABSTRAK
Kegiatan pariwisata merupakan salah satu sektor vital yang dapat diandalkan oleh masyarakat suatu desa untuk memperoleh pendapatan tambahan. Desa Bedono merupakan salah satu desa pesisir yang terletak di Kecamatan Sayung, Kabupaten Demak. Sebagai salah satu desa pesisir, Desa Bedono mengalami tekanan dari aktivitas di darat maupun di lautan. Dampak yang paling terlihat adalah rusaknya infrastruktur akibat banjir rob. Hal ini tentu menghambat wisatawan yang ingin datang berkunjung ke Desa Bedono. Penelitian ini bertujuan untuk mengetahui faktor-faktor yang mempengaruhi wisatawan untuk datang ke Desa Bedono. Pengumpulan data dilakukan dengan kuesioner berisi pertanyaan tertutup dengan jumlah responden sebanyak 100. Pengolahan data menggunakan regresi logistic dengan bantuan software SPSS. Hasil penelitian ini menunjukkan bahwa faktor yang mempengaruhi wisatawan untuk datang ke Desa Bedono ada tiga, yaitu: respon warga desa terhadap banjir rob $\left(X_{1}\right)$, prioritas masalah lingkungan $\left(X_{3}\right)$ dan jenis wisata yang ditawarkan $\left(\mathrm{X}_{11}\right)$ dilihat dari nilai significance yang berada di bawah $1 \%$ dan $5 \%$. Setelah mengetahui faktor-faktor yang mempengaruhi wisatawan untuk datang ke Desa Bedono, diharapkan warga dapat memaksimalkan potensi sehingga dapat meningkatkan jumlah wisatawan.
\end{abstract}

Kata Kunci : Regresi Logistik, Ekowisata, Pesisir, Bedono

\section{ABSTRACT}

\section{APPLICATION OF LOGISTIC REGRESSION IN DETERMINING FACTORS AFFECTING THE NUMBER OF ECOTOURISM ASSESSMENT IN BEDONO VILLAGE. Tourism activities are one of the}

DOI: https://doi.org/10.31186/jenggano.5.1.11-22 
vital sectors that can be relied upon by the people of a village to obtain additional income. Bedono Village is a coastal village located in Sayung Subdistrict, Demak Regency. As one of the coastal villages, Desa Bedono experiences pressure from activities on land and in the ocean. The most noticeable impact is damage to infrastructure due to tidal flooding. This certainly inhibits tourists who want to come to visit Bedono Village. This study aims to determine the factors that influence tourists to come to the village of Bedono. Data collection was carried out with a questionnaire containing closed questions with 100 respondents. Data processing used logistic regression with the help of SPSS software. The results of this study indicate that there are three factors influencing tourists to come to Bedono Village, namely: villagers' responses to tidal floods $(X 1)$, priority environmental problems (X3) and types of tours offered (X11) seen from the significance value at under $1 \%$ and $5 \%$. After knowing the factors that influence tourists to come to Bedono Village, it is hoped that residents can maximize their potential so that they can increase the number of tourists.

Keywords : Logistic Regression, Ecotourism, Coastal, Bedono

\section{PENDAHULUAN}

Kegiatan pariwisata merupakan salah satu sektor vital yang dapat diandalkan oleh masyarakat suatu desa untuk memperoleh pendapatan tambahan. Peran pariwisata dalam rangka meningkatkan perekonomian suatu desa sangat besar, diantaranya yaitu menciptakan lapangan kerja baru, memberdayakan masyarakat sekitar serta pada akhirnya akan meningkatkan perekonomian desa tersebut (Wihasta \& Prakoso, 2012). Kualitas daya tarik wisata merupakan faktor penting yang menentukan minat wisatawan untuk mengunjungi suatu destinasi wisata, oleh karena itu pengembangan wisata harus terus dilakukan (Basiya \& Rozak, 2012). Permasalahan yang sering timbul dalam pengembangan desa wisata antara lain kurangnya inovasi dalam pengembangan wisata, desa wisata yang dikelola oleh masyarakat yang kurang kompeten dan kurangnya spesialisasi atau diversiasi daya tarik wisata (Hermawan, 2017).

Desa Bedono merupakan salah satu desa pesisir yang terletak di Kecamatan Sayung, Kabupaten Demak. Kabupaten Demak yang letaknya berdekatan dengan Kota Semarang menjadikan wilayah Kabupaten Demak sebagai destinasi wisata warga Kota Semarang dan sekitarnya, salah satunya yaitu kawasan ekowisata di Desa Bedono (Rohman, Ghofar, \& Saputra, 2016). Wisata yang ada di Desa Bedono diantaranya adalah hutan mangrove, wisata pantai dan wisata religi ziarah makam terapung Mbah Mudzakir. Desa Bedono sebagai desa pesisir menyebabkan desa tersebut mendapatkan tekanan dari berbagai aktivitas dan fenomena yang terjadi di darat maupun di laut. Fenomena - fenomena yang terjadi di daratan seperti erosi banjir dan aktivitas yang dilakukan 
seperti pembangunan pemukiman, pembabatan hutan mangrove, pembangunan tambak dan sebagainya pada akhirnya akan berdampak pada ekosistem pantai. Demikian pula fenomena fenomena di lautan seperti pasang surut air laut dan penurunan permukaan tanah (Pinto, 2016). Fenomena penurunan permukaan tanah ini juga terjadi di Desa Bedono.

Penurunan permukaan muka tanah akan menyebabkan terjadinya rob akibat naiknya muka air laut. Terjadinya rob menjadi masalah yang perlu diperhatikan karena memiliki dampak yang serius bagi masyarakat (Pickering, 2012). Rob adalah banjir akibat pasang air laut yang menggenangi lahan/kawasan pesisir yang lebih rendah dari permukaan air laut rata-rata atau mean sea level (Kusuma, Setyowati, \& Suhandini, 2016). Dampak rob yakni tergenangnya infrastruktur desa, seperti jalanan, fasilitas pendidikan dan perumahan warga. Dampak banjir rob terhadap rumah dan bangunan menyebabkan lantai rumah atau bangunan pada umumnya rusak, seperti retak, miring, lapuk dan tenggelam tanah urugan, sedangkan terhadap sarana dan prasarana menyebabkan jalan becek, sistem drainase tidak lancar, dan air tanah asin/payau akibat masuknya air laut pasang pada air tanah (Desmawan \& Sukamdi, 2012).

Desa Bedono yang mengalami penurunan permukaan tanah akhirnya juga sering terkena banjir rob. Dampaknya yaitu infrastruktur di Desa Bedono, khususnya jalanan sebagai akses darat menuju Desa rusak parah. Permasalahan transportasi ini tentu mempengaruhi wisatawan yang akan datang ke Desa Bedono (Soebiyantoro, 2010). Dampak lain dari yang ditimbulkan akibat seringnya banjir rob yang terjadi di Desa Bedono adalah degradasi lahan mangrove yang meliputi penurunan tanah, kenaikan muka air laut dan erosi (Zaky, Suryono, \& Pribadi, 2012). Selain infrastruktur jalan dan kondisi lahan mangrove, tentu ada beberapa hal yang mempengaruhi wisatawan yang akan datang ke Desa Bedono.

Penelitian yang pernah dilakukan mengenai ekowisata di Desa Bedono yaitu kajian kondisi lahan mangrove (Zaky et al., 2012), dalam penelitian ini dilakukan kajian mengenai degradasi lahan mangrove yang ada di Desa Bedono. Kemudian penelitian mengenai pengembangan kegiatan konservasi mangrove (Abiyoga, Suryanti, \& Muskananfola, 2013) yang dari penelitian ini didapat alternatif strategi berupa menjaga dan meningkatkan kelestarian ekosistem mangrove, meningkatkan koordinasi dengan stakeholders dan melakukan konsultasi dalam bidang ekowisata mangrove. Penelitian mengenai partisipasi masyarakat dalam pengembangan kawasan ekowisata oleh Rohman (2016) juga berhasil mengetahui bahwa terdapat korelasi antara pemahaman masyarakat local mengenai ekowisata dengan tingkat partisipasi mereka. Selain itu Ugy (2010) melakukan penelitian mengenai pengaruh ketersediaan sarana prasarana, sarana transportasi terhadap kepuasan wisatawan yang

DOI: https://doi.org/10.31186/jenggano.5.1.11-22 
berdasarkan penelitian tersebut dapat diketahui bahwa peningkatan sarana prasarana serta transportasi akan meningkatkan kepuasan wisatawan. Berdasarkan penelitian yang telah ada tersebut, penulis ingin mengembangkan penelitian sebelumnya untuk mengetahui faktor yang mempengaruhi jumlah wisatawan yang datang ke Desa Bedono dengan mempertimbangkan faktor lingkungan, sarana prasarana dan administrasi desa.

Menggunakan analisis dari regresi logistik, penilitian ini bertujuan untuk mengetahui faktor-faktor yang mempengaruhi jumlah wisatawan yang datang ke ekoswisata di Desa Bedono. Faktor-faktor tersebut memilki peran penting dalam pengembangan pariwsata Desa Bedono (Satria, 2009). Pengembangan pariwisata desa dapat memberikan dampak besar terhadap perekonomian desa (Hermawan, 2016). Hal ini karena isu utama dalam pengembangan desa wisata adalah mengenai kontribusi positif aktivitas pariwisata di desa wisata terhadap kehidupan ekonomi masyarakat lokal (Hariyanto, 2016). Setelah mengetahui faktorfaktor tersebut, diharapkan masyarakat dapat memberi perhatian lebih terhadap faktor terkait sehingga dapat meningkatkan jumlah wisatawan serta meningkatkan perekonomian desa.

\section{MATERI DAN METODE}

Penelitian ini dilakukan di Desa Bedono, Kecamatan Sayung, Kabupaten Demak. Penelitian ini dilakukan antara bulan Juli sampai dengan Agustus 2019. Dalam penelitian ini digunakan metode studi kasus (case studies), yaitu suatu penelitian yang dilakukan secara intensif, terinci dan mendalam terhadap suatu organisasi, lembaga atau gejala tertentu.

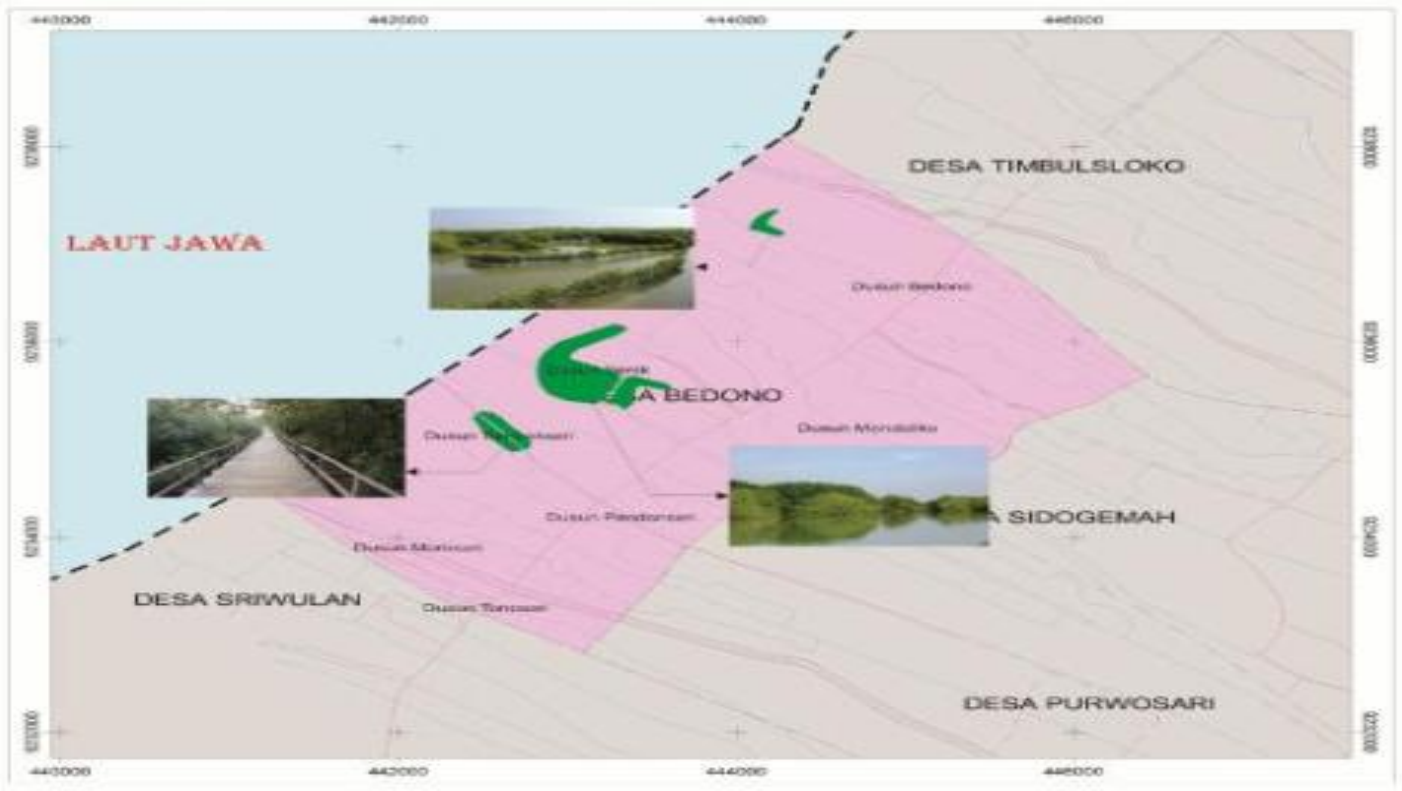

Gambar 1. Peta Desa Bedono 
Pada penelitian ini menggunakan analisis deskriptif kuantitatif dan didukung dengan analisis kualitatif. Analisis faktor - faktor yang mempengaruhi jumlah wisatawan dilakukan secara kuantitatif yaitu dengan menggunakan analisis regresi logistik dan software yang digunakan adalah SPSS. Regresi logistik sering digunakan untuk menjelaskan model yang menghubungkan satu variabel dependen nonmetrik dan beberapa variabel independen-metrik dan / atau non-metrik. Tujuan utama dari regresi logistik adalah untuk memahami perbedaan kelompok dan untuk memprediksi kemungkinan bahwa suatu entitas (individu atau objek) akan menjadi milik kelas atau kelompok tertentu berdasarkan pada beberapa variabel independen metrik tersebut. Program SPSS digunakan untuk mencari hubungan korelasi antara faktor lingkungan dan desa terhadap jumlah wisatawan yang datang.

Dalam penelitian ini digunakan regresi logistik untuk mengetahui faktor-faktor yang mempengaruhi wisatawan untuk datang ke ekowisata Desa Bedono, kami menetapkan variabel dependen (Y) sebagai jumlah wisatawan yang datang ke Desa Bedono. Nilai 1 (satu) diberikan ketika wisatawan bersedia untuk berkunjung ke ekowisata Desa Bedono; sedangkan skor 0 (nol) diberikan untuk jawaban sebaliknya. Himpunan variabel independen (Xj), kami menggunakan tiga belas variable yang diolah dengan modelnya kemudian sebagai berikut:

$Y=\beta_{0}+\beta_{1} X_{1}+\beta_{2} X_{2}+\beta_{3} X_{3}+\beta_{4} X_{4}+\beta_{5} X_{5}+\beta_{6} X_{6}+\beta_{7} X_{7}+\beta_{8} X_{8}+$ $\beta_{9} X_{9}+\beta_{10} X_{10}+\beta_{11} X_{11}+\beta_{12} X_{12}+\beta_{13} X_{13}+\varepsilon$

Dimana $\beta_{0}$ merupakan nilai konstan; $\beta_{j}$ merupakan koefisien regresi $(j=1,2, \ldots, 13) ; X_{1}$ merupakan reaksi warga terhadap rob; $X_{2}$ merupakan persepsi warga mengenai penyebab rob; $X_{3}$ merupakan prioritas permasalahan lingkungan; $X_{4}$ merupakan tingkat manfaat keberadaan mangrove; $X_{5}$ merupakan peran keberadaan mangrove; $X_{6}$ merupakan kondisi mangrove di sekitar rumah warga; $X_{7}$ merupakan usaha perbaikan ekosistem mangrove; $X_{8}$ merupakan pengaruh mangrove terhadap kehidupan warga; $X_{9}$ merupakan aktivitas ekonomi yang dilakukan warga berkaitan dengan mangrove; $X_{10}$ merupakan efek adanya ekowisata; $X_{11}$ merupakan jenis-jenis wisata di Desa Bedono; $X_{12}$ merupakan keuntungan adanya wisata; $X_{13}$ merupakan prioritas masalah yang berkaitan dengan aktivitas ekonomi ; dan $\varepsilon$ merupakan nilai error.

Nilai $b_{0}, b_{1}, \ldots, b_{13}$ sebagai penaksir tidak bias dari $\beta$ dapat ditemukan dengan menggunakan metode maximum likelihood. Kemungkinan $L$ diberikan oleh distribusi probabilitas gabungan yang dievaluasi pada jumlah yang diamati $Y_{i}$, oleh karena itu: 


$$
L\left(b_{0}, b_{1}, \ldots, b_{13}\right)=\frac{\prod_{i=1}^{n} e^{y_{1}\left(b_{0}+b_{1} X_{i 1}+\cdots+b_{13} z_{i 13}\right)}}{\prod_{i=1}^{n}\left(1+e^{\left.b_{0}+b_{1} X_{i 1}+\cdots+b_{13} z_{i 13}\right)}\right.}
$$

Probabilitas yang diprediksi dari warga milik kelompok/grup tertentu, contohnya, 1 atau 0 dapat dihitung dengan menggunakan rumus untuk fungsi distribusi kumulatif dari distribusi logistik standar. Sebagai contoh, probabilitas yang diprediksi dari wisatawan datang termasuk dalam kelompok 1, yaitu, ia bersedia untuk datang ke Desa Bedono adalah:

$$
\operatorname{Pr}(Y=1)=\frac{e^{\left(b_{0}+b_{1} X_{i 1}+\cdots+b_{13} X_{13}\right)}}{1+e^{\left(b_{0}+b_{1} X_{i 1}+\cdots+b_{13} X_{13}\right)}}
$$

Penentuan responden dengan teknik purposive sampling kepada masyarakat lokal, yang artinya responden dipilih berdasarkan atas tujuan tertentu dari peneliti (Collins, Onwuegbuzie, \& Jiao, 2007). Kuesioner yang dipertanyakan kepada responden, berupa pernyataan tertutup mengenai partisipasi masyarakat dalam pengembangan ekowisata di Desa Bedono. Setiap pernyataan yang diajukan, responden hanya perlu menjawab 1 (satu) dari pilihan jawaban yang tersedia. Jawaban-jawaban yang tercantum dalam kuesioner masing-masing akan diberi skor. Selanjutnya adalah menganalisis data yang telah didapatkan dengan mengggunakan model analisis deskriptif.

\section{HASIL DAN PEMBAHASAN}

Studi kasus ini dilakukan di Desa Bedono, Demak, Indonesia, untuk mengetahui keinginan pengunjung untuk datang ke Desa Bedono. Salah satu syarat untuk ikut serta dalam penelitian ini adalah tinggal di dusun Bedono, Pandansari dan Morosari serta sudah berpenghasilan atau memiliki pekerjaan yang spesifik. Potensial partisipan dalam penelitian ini adalah ketika pertama kali ditanya dan setuju untuk menjadi responden. Terdapat seratus responden dalam penelitian ini. Profil responden dapat dilihat pada Tabel 1.

\begin{tabular}{|c|c|c|c|c|c|}
\hline No & Variabel & Persentase & No & Variabel & Persentase \\
\hline \multirow[t]{4}{*}{1} & Desa & & 3 & Pendidikan & \\
\hline & Bedono & 30 & & Sekolah Dasar & 15 \\
\hline & $\begin{array}{l}\text { Pandan } \\
\text { sari }\end{array}$ & 32 & & SMP & 20 \\
\hline & Morosari & 40 & & SMA & 15 \\
\hline
\end{tabular}

Tabel 1. Profil Responden

16 


\begin{tabular}{|c|c|c|c|c|c|}
\hline No & Variabel & Persentase & No & Variabel & Persentase \\
\hline \multirow[t]{7}{*}{2} & Pekerjaan & & & Diploma & 19 \\
\hline & Buruh & 14 & & Lainnya & 23 \\
\hline & Nelayan & 17 & 4 & $\begin{array}{l}\text { Pendapatan } \\
\text { keluarga }\end{array}$ & \\
\hline & Ojek & 21 & & $\begin{array}{l}\text { Kurang } \\
\text { Rp 1.000.000 }\end{array}$ & 29 \\
\hline & Pedagang & 14 & & $\begin{array}{l}\text { Rp 1.000.000- } \\
\text { Rp 2.500.000 }\end{array}$ & 23 \\
\hline & PNS & 14 & & $\begin{array}{l}\text { Rp 2.500.000- } \\
\text { Rp 5.000.000 }\end{array}$ & 27 \\
\hline & Lainnya & 22 & & $\begin{array}{l}\text { Lebih } \\
\text { Rp } 5.000 .000\end{array}$ & 23 \\
\hline
\end{tabular}

Dalam rangka mengetahui Kesiapan warga Desa Bedono dalam menyambut wisatawan yang berkunjung, kami menanyakan bagaimana kondisi rumah warga sekitar yang dapat menjadi daya tarik dalam pembangunan desa wisata, contohnya, permanen, semi permanen, dan tidak permanen. Terdapat $53 \%$ warga sekitar memiliki rumah yang permanen, terdapat $39 \%$ warga sekitar memiliki rumah semi permanen dan terdapat $10 \%$ warga sekitar memiliki rumah tidak permanen. Dari data tersebut dapat dipetakan untuk rumah-rumah dalam menyiapkan desa wisata di Bedono, yang mana rumah yang permanen dan semi permanen sebagai ikon di Desa Bedono. Hasil data tersebut dapat dilihat pada Gambar 2.

60

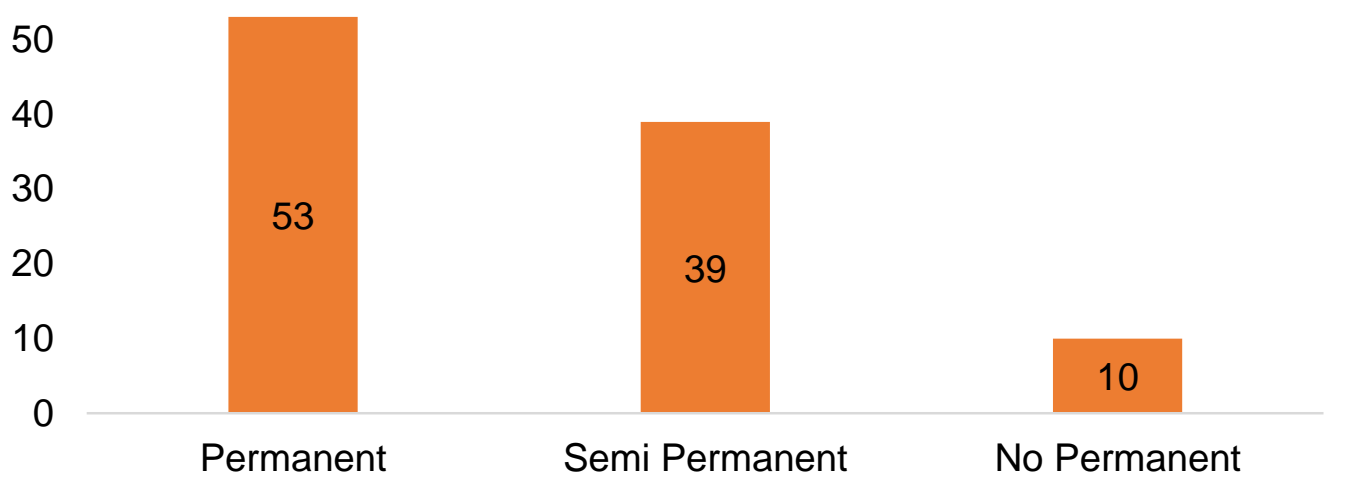

Gambar 2. Kondisi Rumah

Perumusan regresi logistik disesuaikan dengan pemodelan di materi dan metode. Tabel 2 sebagai kesimpulan atas hasil estimasi koefisien DOI: https://doi.org/10.31186/jenggano.5.1.11-22 
persamaan logit sehubungan dengan keinginan pengunjung untuk datang ke Desa Bedono. Hanya 3 variabel independen secara statistik signifikan: $\mathrm{X} 1, \mathrm{X} 11$ dengan 1\% signifikan; $\mathrm{X} 3$ dengan 5\% signifikan. Hasil pemodelan ini harus diperhitungan menggunakan Nagelkerke $R^{2}$ (Hong \& Chao, 2007)- (Herrero, et al., 2003), dimana memiliki nilai yang tinggi sebesar 0.792 . Hal ini menunjukan bahwa variabel independen dapat menjelaskan $79.2 \%$ atas keanekaragaman variabel dependen. Hasil perhitungan ini juga mempertimbangkan pengujian Hosmer and Lemeshow yang sudah banyak dilakukan sebagai validasi (Papageorgiou \& Wells, 2009)- (Kramer \& Zimmerman, 2007), menunjukan bahwa model ini signifikan dengan nilai sebesar 0.612, yang mana diatas level signifikan 5\% (Bertolini, D'amico, Nardi, Tinazzi, \& Apolone, 2000).

Prioritas permasalahan lingkungan memiliki nilai statistik yang signifikan berdasarkan tabel 2. Hal ini dapat disimpulkan bahwa lingkungan di Bedono memiliki pengaruh untuk pengunjung datang ke Desa Bedono. Penting adanya perbaikan fasilitas, penangulangan rob dan air bersih agar pengunjung dapat leluasa berkeliling Desa Bedono. Bagaimanapun, $X_{2}$ tidak memiliki pengaruh yang signifikan. Ini menunjukan bahwa penyebab terjadinya rob tidak begitu diperhatikan oleh pengunjung. Tapi hal ini kontras dengan respon yang akan dilakukan apabila terjadi rob $\left(X_{1}\right)$ yang memiliki signifikansi secara statistik. Jika ditinjau lebih lanjut, masyarakat harus pindah atau tinggal tanpa memperhatikan penyebab rob itu terjadi.

Tiada variabel independen yang signifikan jika melibatkan tanaman mangrove untuk meningkatkan keinginan pengunjung untuk datang ke Desa Bedono, sebagai contoh, $X_{4}, X_{5}, X_{6}, X_{7}, X_{8}$. Hal ini menunjukan bahwa tanaman magrove hanya dikenal secara fungsional untuk penahan atas air laut dan angin kencang ke desa. Tanaman mangrove bukan sebagai ciri khas atau daya tarik sendiri warga untuk datang ke Desa Bedono.

Berbicara mengenai kondisi di Desa Bedono, berbagai jenis pariwisata memiliki nilai signifikan secara statistik $\left(X_{11}\right)$. Beragam objek wisata di Desa Bedono, contohnya yaitu tracking mangrove, kampung tenggelam, makam mbah mudzakir, pantai mor. Tetapi terjadi sebuah perbedaan yang signifikan antara pariwisata dan perekonomian, pengunjung tidak memperhatikan bagaimana kondisi ekonomi sekitar $\left(X_{9}\right)$, dampak dan manfaat adanya wisatawan di Desa Bedono $\left(X_{10}\right)\left(X_{11}\right)$, dan masalah prioritas untuk meningkatkan aktivitas ekonomi $\left(X_{12}\right)$. Pada dasarnya, aktivitas perekonomian di Desa Bedono tidak berpengaruh ke pengunjung namun ragam wisata sebagai daya tarik atas pemilihan pengunjung untuk datang ke Desa Bedono. 
E-ISSN: 2527-5186. P-ISSN: 2615-5958

Jurnal Enggano Vol. 5, No. 1, April 2020: 11-22

Tabel 2. Hasil Regresi Logistik

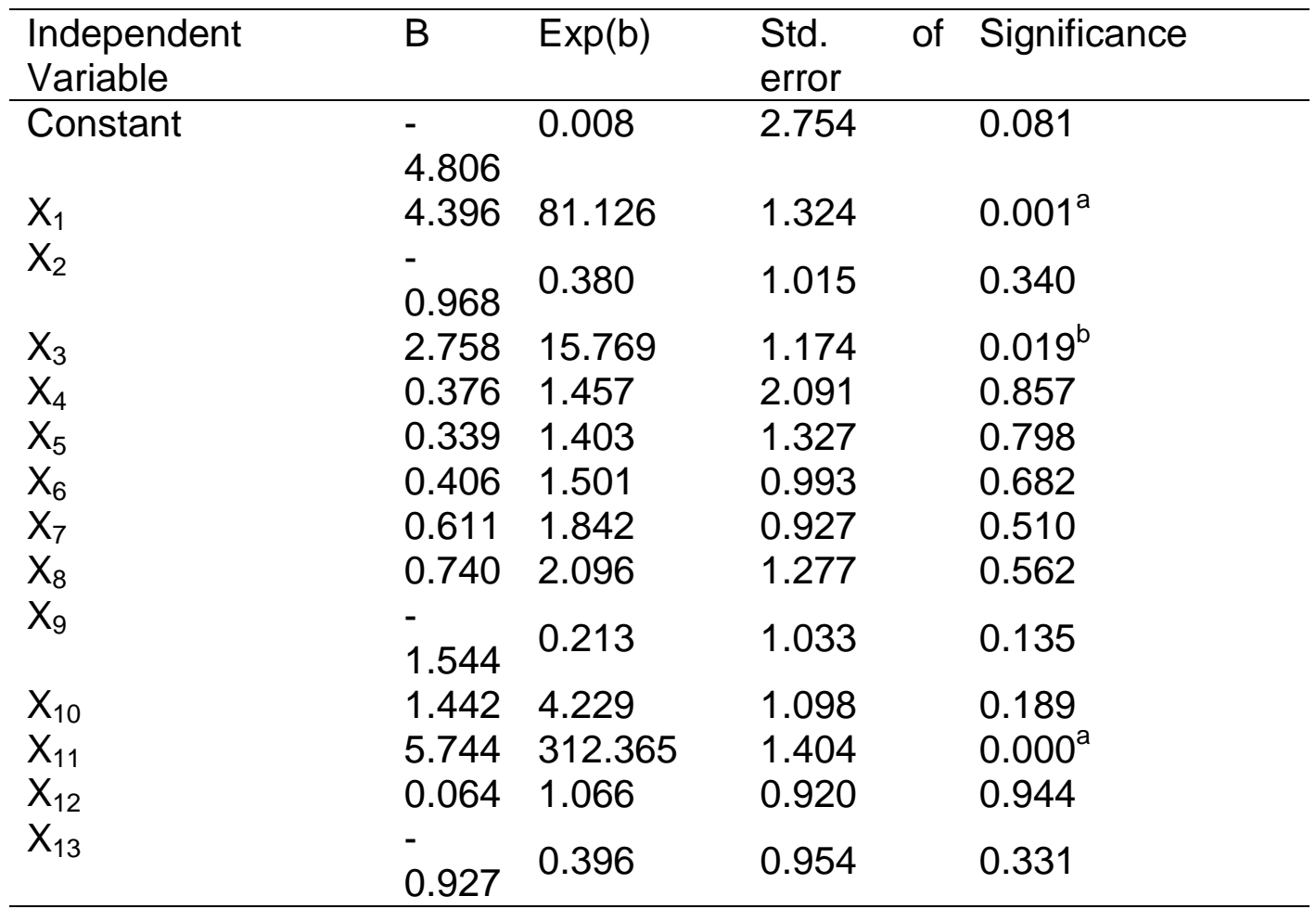

a Level signifikan pada $1 \%$

${ }^{\mathrm{b}}$ Level signifikan pada $5 \%$

Pendekatan regresi logistik bukan hanya mengetahui variabel yang signifikan yang mana berpengaruh kepada keinginan pengunjung untuk datang ke Desa Bedono. Tetapi hasil pemodelan ini dapat dipergunakan untuk memprediksi perilaku pengunjung lainnya untuk datang ke Desa Bedono. Perumusan berdasarkan pengembangan rumus regresi logistik. Sebagai contoh berikut ini.

Ada seorang pengunjung Desa Bedono yang identifikasi atas keinginannya untuk datang ke Desa Bedono. Dia tidak melakukan apapun jika terjadi rob dan mengerti penyebabnya. Infrastruktur desa adalah prioritas utama. Kondisi mangrove bukan suatu masalah yang harus dia pikirkan. Dia hanya tertarik dengan dua wisata di Desa Bedono, i.e., makam mbah mudzakir dan pantai mor. Selebihnya, perkembangan perekonomian desa tidak begitu dihiraukan. Berdasarkan penjelasan tersebut dapat disimpulkan bahwa $X_{1}$ adalah $0, X_{2}$ adalah $1, X_{3}$ adalah 1 , $X_{4}$ adalah $0, X_{5}$ adalah $0, X_{6}$ adalah $0, X_{7}$ adalah $0, X_{8}$ adalah $0, X_{9}$ adalah $0, X_{10}$ adalah $0, X_{11}$ adalah $1, X_{12}$ adalah 0 . Sehingga dapat dilakukan perhitungan menggunakan rumus yang telah dijelaskan sebelumnya, probilitas pengunjung untuk datang ke Desa Bedono sebesar 0,94.

DOI: https://doi.org/10.31186/jenggano.5.1.11-22 
Di mana hanya $\mathrm{X} 1, \mathrm{X} 3$, dan $\mathrm{X} 11$ yang signifikan. Berdasarkan perhitungan tersebut, memiliki peluang sebesar 0,94 di atas titik potong sebesar 0,5 . Kita dapat simpulkan bahwa orang tersebut ingin untuk datang ke Desa Bedono.

\section{KESIMPULAN}

Adapun tujuan dari penelitian ini adalah mengidentifikasi variabel yang mempengaruhi pengunjung untuk datang ke Desa Bedono dan memodelkan dan memprediksi peluang kedatangan pengunjung. Studi kasus penelitian di Desa Bedono, Demak, Indonesia. Hasil penelitian menunjukan bahwa hanya 3 variabel yang signifikan berpengaruh dari 12 variabel yang ada. Tiga variabel tersebut adalah prioritas permasalahan lingkungan, respon terhadap rob dan berbagai jenis wisata yang ada (perhatikan tabel 2). Fasilitas di Desa Bedono sangatlah penting untuk diperhatikan terlebih dalam peristiwa alam yang sering terjadi didukung variasi pariwisata yang ditawarkan oleh Desa Bedono. Sehingga, fasilitas yang memadai, minimalisir terjadi rob dan variasi pariwisata yang ditingkatkan akan meningkatkan pengunjung untuk datang ke Desa Bedono.

\section{UCAPAN TERIMA KASIH}

Penulis menyampaikan terima kasih kepada Universitas Diponegoro, yang telah memberikan dana; selain APBN DPA LPPM tahun anggaran 2019 dalam pelaksanaan kegiatan IPTEK Bagi Desa Binaan UNDIP (IDBU) dan mahasiswa KKN Tematik Desa Bedono 2019.

\section{DAFTAR PUSTAKA}

Abiyoga, R., Suryanti, S., \& Muskananfola, M. R. (2018). Strategi Pengembangan Kegiatan Konservasi Mangrove Di Desa Bedono Kabupaten Demak. Management of Aquatic Resources Journal, 6(3), 293-301.

Basiya, R., \& Rozak, H. A. (2012). Kualitas Dayatarik Wisata, Kepuasan Dan Niat Kunjungan Kembali Wisatawan Mancanegara Di Jawa Tengah. Jurnal Ilmiah Dinamika Kepariwisataan, 11(2).

Bertolini, G., D'amico, R., Nardi, D., Tinazzi, A., \& Apolone, G. (2000). One model, several results: the paradox of the Hosmer-Lemeshow goodness-of-fit test for the logistic regression model. Journal of Epidemiology and Biostatistics, 251-300. 
Collins, K. M. T., Onwuegbuzie, A. J., \& Jiao, Q. G. (2007). A Mixed Methods Investigation of Mixed Methods Sampling Designs in Social and Health Science Research. Journal of Mixed Methods Research, 1(3), 267-294.

Desmawan, B. T., \& Sukamdi, S. (2012). Adaptasi masyarakat kawasan pesisir Terhadap Banjir Rob di Kecamatan Sayung, Kabupaten Demak, Jawa Tengah. Jurnal Bumi Indonesia, 1(1).

Hariyanto, O. I. B., 2016, Destinasi Wisata Budaya Dan Religi Di Cirebon, Jurnal Ecodemica: Jurnal Ekonomi, Manajemen, dan Bisnis, 4(2), 214222.

Hermawan, H., 2016, Dampak pengembangan Desa Wisata Nglanggeran Terhadap Ekonomi Masyarakat Lokal, Jurnal Pariwisata, 3(2), 105117.

Hermawan, H. (2017). Pengaruh Daya Tarik Wisata, Keselamatan, Dan Sarana Wisata Terhadap Kepuasan Serta Dampaknya Terhadap Loyalitas Wisatawan: Studi Community Based Tourism Di Gunung Api Purba Nglanggeran. JURNAL MEDIA WISATA: Wahana Informasi Pariwisata, 15(1).

Herrero, M. J., Blanch, J., Peri, J. M., De Pablo, J., Pintor, L., \& Bulbena, A. (2003). A validation study of the hospital anxiety and depression scale (HADS) in a Spanish population. General Hospital Psychiatry, 277-283.

Hong, W., \& Chao, R. (2007). A Comparative Test of Two Employee Turnover. International Journal of Management, 216-229.

Kramer, A. A., \& Zimmerman, J. E. (2007). KraAssessing the calibration of mortality benchmarks in critical care: The Hosmer-Lemeshow test revisited*. Critical Care Medicine, 2052-2056.

Kusuma, M. A., Setyowati, D. L., \& Suhandini, P, 2016, Dampak Rob terhadap Perubahan Sosial Masyarakat di Kawasan Rob Desa Bedono Kecamatan Sayung Kabupaten Demak, Journal of Educational Social Studies, 5(2), 121-127.

Papageorgiou, C., \& Wells, A. (2009). A Prospective Test of the Clinical Metacognitive Model of Rumination and Depression. International Journal of Cognitive Therapy, 123-131.

DOI: https://doi.org/10.31186/jenggano.5.1.11-22 
Pickering, M. D., Wells, N. C., Horsburgh, K. J., \& Green, J. A. M. (2012). The Impact Of Future Sea-Level Rise On The European Shelf Tides. Continental Shelf Research

Pinto, Z. (2015). Kajian Perilaku Masyarakat Pesisir Yang Mengakibatkan Kerusakan Lingkungan (Studi Kasus di Pantai Kuwaru, Desa Poncosari, Kecamatan Srandakan, Kabupaten Bantul, Provinsi DIY). Jurnal Wilayah dan Lingkungan, 3(3), 163-174.

Rohman, F., Ghofar, A., \& Saputra, S. W., 2016, Partisipasi masyarakat dalam pengembangan kawasan ekowisata di Desa Bedono Kecamatan Sayung Kabupaten Demak, Management of Aquatic Resources Journal, 5(2), 61-69.

Satria, D, 2009, Strategi pengembangan ekowisata berbasis ekonomi lokal dalam rangka program pengentasan kemiskinan di wilayah Kabupaten Malang, Journal of Indonesian Applied Economics, 3(1).

Soebiyantoro, U. (2010). Pengaruh ketersediaan sarana prasarana, sarana transportasi terhadap kepuasan wisatawan. Jurnal Manajemen Pemasaran, 4(1), pp-16.

Wihasta, C. R., \& Prakoso, H. B. S., 2012, Perkembangan Desa Wisata Kembang Arum dan Dampaknya Terhadap Kondisi Sosial Ekonomi Masyarakat Donokerto Kecamatan Turi, Jurnal Bumi Indonesia, 1(1).

Zaky, A. R., Suryono, C. A., \& Pribadi, R., 2012, Kajian Kondisi Lahan Mangrove di Desa Bedono, Kecamatan Sayung, Kabupaten Demak dan Kelurahan Mangunharjo, Kecamatan Tugu, Kota Semarang, Journal Of Marine Research, 1(2), 88-97. 